\title{
Effects of HRM Practices on Chinese Firms' Organizational Performance: The Moderating Effect of CEO Support
}

\author{
Jaehoon Rhee ${ }^{1}$, Xiaofei Zhao ${ }^{1}$ \& Choonghyun $\mathrm{Kim}^{1}$ \\ ${ }^{1}$ School of Management, Yeungnam University, Korea \\ Correspondence: Xiaofei Zhao, School of Management, Yeungnam University, Gyeongsan, Gyeongbuk 712-749, \\ Korea. Tel: 82-010-4072-8595. E-mail: qiaoke@ynu.ac.kr
}

Received: April 23, 2014 Accepted: May 19, 2014 Online Published: June 25, 2014

doi:10.5539/ass.v10n13p210 URL: http://dx.doi.org/10.5539/ass.v10n13p210

\begin{abstract}
There has been growing interest in the relationship between HRM practices and organizational performance, but few studies have provided evidence supporting this relationship by considering the moderating effect of CEO support. Therefore, this study intends to examine the effects of various HRM practices on organizational performance and the moderating effect of CEO support on the relationship between HRM practices and organizational performance through a survey on 215 Chinese firms. The results indicate a positive relationship between HRM practices and organizational performance and verify the moderating effect of CEO support on this relationship. This study is the first one on demonstrating the moderating effect of CEO support on the relationship between HRM practices and organizational performance in the context of Chinese firms. These findings may help adding knowledge to the Chinese firms' CEOs while considering about making HR policies and HRM activities which are mainly decided by their attitudes and participations.
\end{abstract}

Keywords: CEO support, compensation, HRM practices, organizational performance, recruitment, training

\section{Introduction}

In recent years, firms have been urged to adopt a variety of performance-enhancing or progressive HRM activities to increase their market share and improve their competitiveness in the global market because HRM plays a critical role in firms' success by having considerable influence on organizational performance. Therefore, strategic HRM is expected to help firms achieve better organizational performance. Abundant studies have documented the significant relationship between HRM practices and organizational performance. Jacob \& Jolly (2012) studies demonstrated that high commitment levels on behalf of the workers are possible when appropriate HRM practices are used. Katou (2008) noted that HRM practices have direct effects on employee attributes such as skills, attitudes, and behaviors (the so-called HRM outcomes), which in turn can enhance organizational performance. Pfeffer (2000) observed that HRM practices reflect an essential method for sustaining organizational performance.

Although, it is generally known that HRM practices are positively related to organizational performance, there remains a need for more robust evidence supporting the HRM-performance relationship in various cultural contexts (Yazam \& Ahmid, 2011). Here another issue is that many researchers have questioned this relationship (Katou, 2008; Gerhart, 2005). Based on these theorems, Becker and Gerhart (1996) suggested some intermediary steps- some moderators' existing in the relationship. Previous studies of HRM practices and organizational performance have found CEO support to be a critical factor influencing the successful implementation of HRM practices and thus organizational performance (Smith, 1991; Martinez, 1993; Seal, 1991; Williamson, 1993). Therefore, this study examines whether there is a positive relationship between HRM practices and organizational performance and whether CEO support moderates this relationship.

\section{Theoretical Background}

As indicated earlier, several studies have tested the relationship between HRM practices and organizational performance and generally provided support for this relationship. In fact, recent studies have gone beyond the analysis of the relationship between various HRM practices and organizational performance, identifying the mechanisms through which HRM practices influence organizational performance (Boselie et al., 2005; Collins \& Smith, 2006; Hailey et al., 2005). Recent reviews of research on this relationship have questioned the 
methodological rigor of previous studies (Wall \& Wood, 2005). This suggests that it is premature to conclude a positive relationship between HRM practices and organizational performance.

In addition, HRM activities such as training, employee participation, compensation, and worker assignment through recruitment and selection processes and internal labor markets have been found to be positively related to firm performance (Kaufman, 1992; Terpstra \& Rozell, 1993; Bartel, 1994). HRM activities can influence the organization indirectly by improving employees' skills and quality and indirectly by increasing their motivation (a system of incentives and an internal job market). Previous studies have generally investigated the relationship between the HRM system and firm performance at the firm level.

In terms of recruitment and organizational performance, studies have shown that valid recruitment tests are useful for recruiting employees (Schuler \& Jackson, 1987) and that an effective recruiting process is positively related to organizational performance (Terpstra \& Rozell, 1993; Martell \& Carroll, 1995). The staff recruitment process plays an essential role in the process of workforce planning. Although recruitment is one of the most difficult tasks facing firms, it has considerable influence on organizational performance, which depends on the right number of workers, appropriate skills, and motivated workers with positive behaviors for organizational performance (GrÖßler \& Zock, 2010). In sum, previous studies have demonstrated a positive relationship between the recruitment process and organizational performance (Terpstra \& Rozell, 1993).

With respect to training and organizational performance, an organization's HR training and development (T\&D) system is a key mechanism through which employees acquire necessary knowledge, skills, and attitudes for achieving organizational goals and gaining a competitive advantage (Peteraf, 1993). It is well known that highly knowledgeable and skilled employees enhance productivity, improve the quality of goods and services, bring about positive process changes, and facilitate the delivery of quality services to customers. In other words, they enhance organizational competitiveness and performance (Yazam \& Ahmid, 2011). Burke and Day (1986) indicated that training has a positive effect on the level of performance.

Many researchers have found that employee participation has a positive effect on organizational performance (Wagner, 1994; Verma, 1995) and increases employees' satisfaction and productivity (Pfeffer, 1994). In addition, profit-sharing programs are more likely to be effective when they involve employees' participation in management (Blinder, 1990). Therefore, work systems entailing employees' participation enhance their motivation as well as their ability to influence work flow quality.

Many studies have examined the effects of incentive compensation on firm performance and found that an advanced compensation system can be a potential source of competitive advantage (Gomez-Mejia \& Wellbourne, 1988). A compensation system based on excellence can increase employee performance (Delaney \& Huselid, 1996) in the same way as a profit-sharing system increases productivity and improves performance by, among others, reducing absenteeism (Kaufman, 1992).In reality, compensation and rewards leads to employees' motivation, commitments, satisfactions(Katou, 2008; ALDamoe, Yazam \& Hamid, 2013) and eventually can enhance productivity, sales, and overall organizational performance (Delaney \& Huselid, 1996; Dreher, 2006). Therefore, there is clear evidence that compensation and reward have considerable influence on organizational performance. Thus the proposed hypothesis is:

H1: HRM practices have positive effects on organizational performance.

H 1-1a: Recruitment has a positive effect on financial performance.

H 1-1b: Recruitment has a positive effect on nonfinancial performance.

H 1-2a: Training has a positive effect on financial performance.

H 1-2b: Training has a positive effect on nonfinancial performance.

H 1-3a: Participation has a positive effect on financial performance.

H 1-3b: Participation has a positive effect on nonfinancial performance.

H 1-4a: Compensation has a positive effect on financial performance.

\section{H 1-4b: Compensation has a positive effect on nonfinancial performance.}

Top management's leadership is crucial and central to the implementation of TQM/HRM practices in any organization (Ahire, 1996; Li, Chen \& Cheung, 2000; Sureshchandar et al., 2001, 2002). An important condition for an effective policy statement by an organization is support by top management, such as the CEO's cognition and will (Smith, 1991; Martinez, 1993; Seal, 1991; Williamson, 1993; Laabs, 1991; Losey, 1993). CEO support is one of the most important forms of organizational support because it facilitates all management activities. For 
the effective implementation of performance-based HRM practices, the necessary management competence includes the HR department and CEO-related factors. Becker and Huselid (1998b) suggested that organizational performance can increase if CEOs are more concerned about performance-based HR policies or if they participate actively in HRM activities. Bowen and Ostroff (2004) emphasized the role of a consensus between managers in delineating their concept of a "strong" HRM system and hypothesized that a strong HRM system is more likely to increase firm performance. Rynes and Rosen (1995) found that top management's support is related to the adoption and success of diversity training programs and influences organizational performance. In general, the role of CEO support in strategic decisions and choices is conceptualized as a process influencing organizational performance. In other words, CEO support may be an important factor influencing the relationship between HRM practices and organizational performance. Thus the proposed hypothesis is:

H2: CEO support moderates the relationship between HRM practices and organizational performance.

H 2-1a: CEO support moderates the relationship between recruitment and financial performance.

$H$ 2-1b: CEO support moderates the relationship between recruitment and nonfinancial performance.

H 2-2a: CEO support moderates the relationship between training and financial performance.

$H$ 2-2b: $C E O$ support moderates the relationship between training and nonfinancial performance.

H 2-3a: CEO support moderates the relationship between participation and financial performance.

$H$ 2-3b: CEO support moderates the relationship between participation and nonfinancial performance.

$H$ 2-4a: CEO support moderates the relationship between compensation and financial performance.

\section{H 2-4b: CEO support moderates the relationship between compensation and nonfinancial performance.}

Firm size and age (two control variables) may influence organizational performance in various contexts (Robert \& Kim, 2007).

Based on the above discussion, Figure 1 shows the aforementioned relationships.

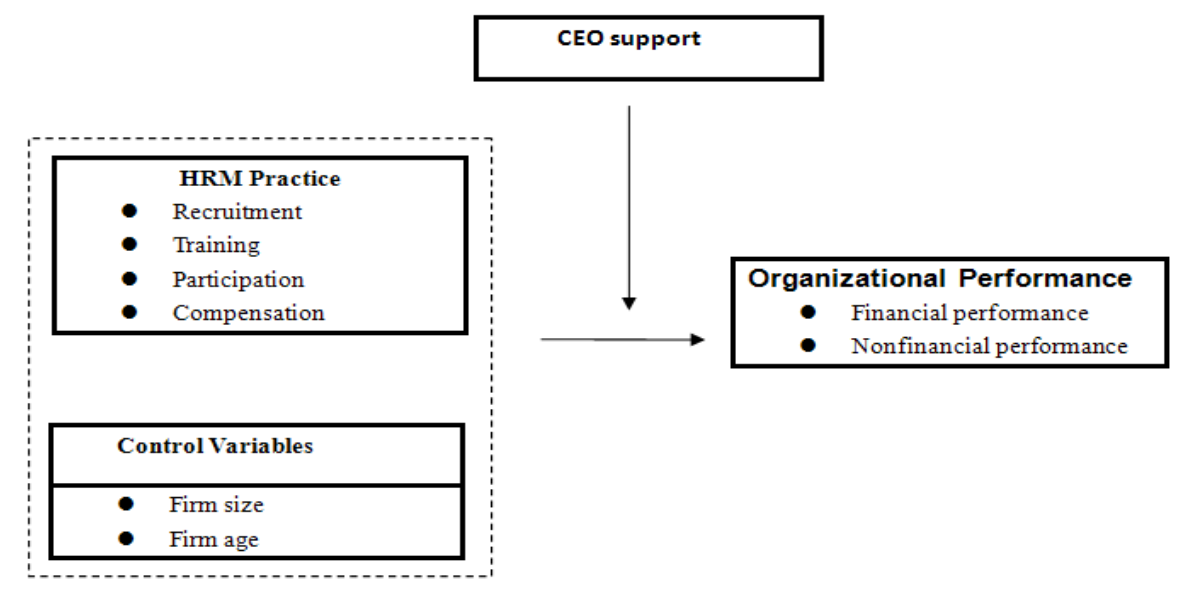

Figure 1. Research model

\section{Methodology}

\subsection{The Population and Sample}

Data of appropriate breadth and depth were obtained by e-mail. Firm-level data were collected by questionnaires mailed to CEOs or senior HR managers. A total of 780 questionnaires were sent, and 215 reliable responses were obtained. Among the respondents, $60.4 \%$ were SMEs, and 39.6\% were large firms. In terms of firm age, 161 were in existence for less than 20 years, accounting for $74.8 \%$ of the sample, and 54 existed for 20 or more (25.2\%). The first mailing returned 172 responses, and the second mailing, 43. Non-response bias was assessed through a comparison between early and late respondents in terms of key constructs, including firm size (the number of employees) and firm age based on a t-test (firm size: $p=0.160$; firm age: $p=0.500$ ). Therefore, non-response bias was not a serious issue. The data were coded and then analyzed using SPSS 19.0. 
The questionnaire had five parts (including demographic statistics). The three main parts were HRM practices, CEO support, and organizational performance. In addition, usual information on firms and respondents was obtained. In addition to demographic information, all the variables were measured on a five-point Likert-type scale ranging from "strongly disagree" (1) to "strongly agree" (5). This scale measured the extent to which the respondents agreed or disagreed with each statement. Table 1 shows the variables, the number of items for each variable, and sources.

\subsection{Analysis}

The descriptive statistics were all results by minimum 1 and maximum 5 . The highest absolute value of skewness was 0.903 , and that of kurtosis was 2.009. They are all in accordance with the normal distribution of skewness $<|2|$, kurtosis $<|4|$ (Hong, 2008). In addition. the KMO value was 0.893. Based on the Bartlett test of sphericity, the significance of the model was $.000\left(\chi^{2}=2941.362 /\right.$ d. $\left.f=435\right)$, which indicates no common method bias. The results of the exploratory factor analysis indicate seven factors with eigenvalues exceeding 1 . The most representative factor accounted for $31.987 \%$ of the variance. The best fit was determined through a principal factor analysis with Varimax rotation. The moderating variable - CEO support-was originally composed of six items. However, because one item (item 1) had a low factor loading, it was omitted. All other loadings exceeded 0.50 , and therefore the remaining items were considered to be significant. In general, the reliability coefficient should be greater than or equal to 0.60 , and a coefficient exceeding 0.80 is considered to indicate a high level of reliability (Fraenkel \& Wallen, 1996). In this study, Cronbach's alpha was used for the reliability analysis. With the exclusion of item 1 for CEO support, Cronbach's alpha for CEO support was 0.838 . Therefore, Cronbach's alpha for all relevant variables exceeded 0.60 , indicating sufficient internal consistency.

Table 1. Factor analysis

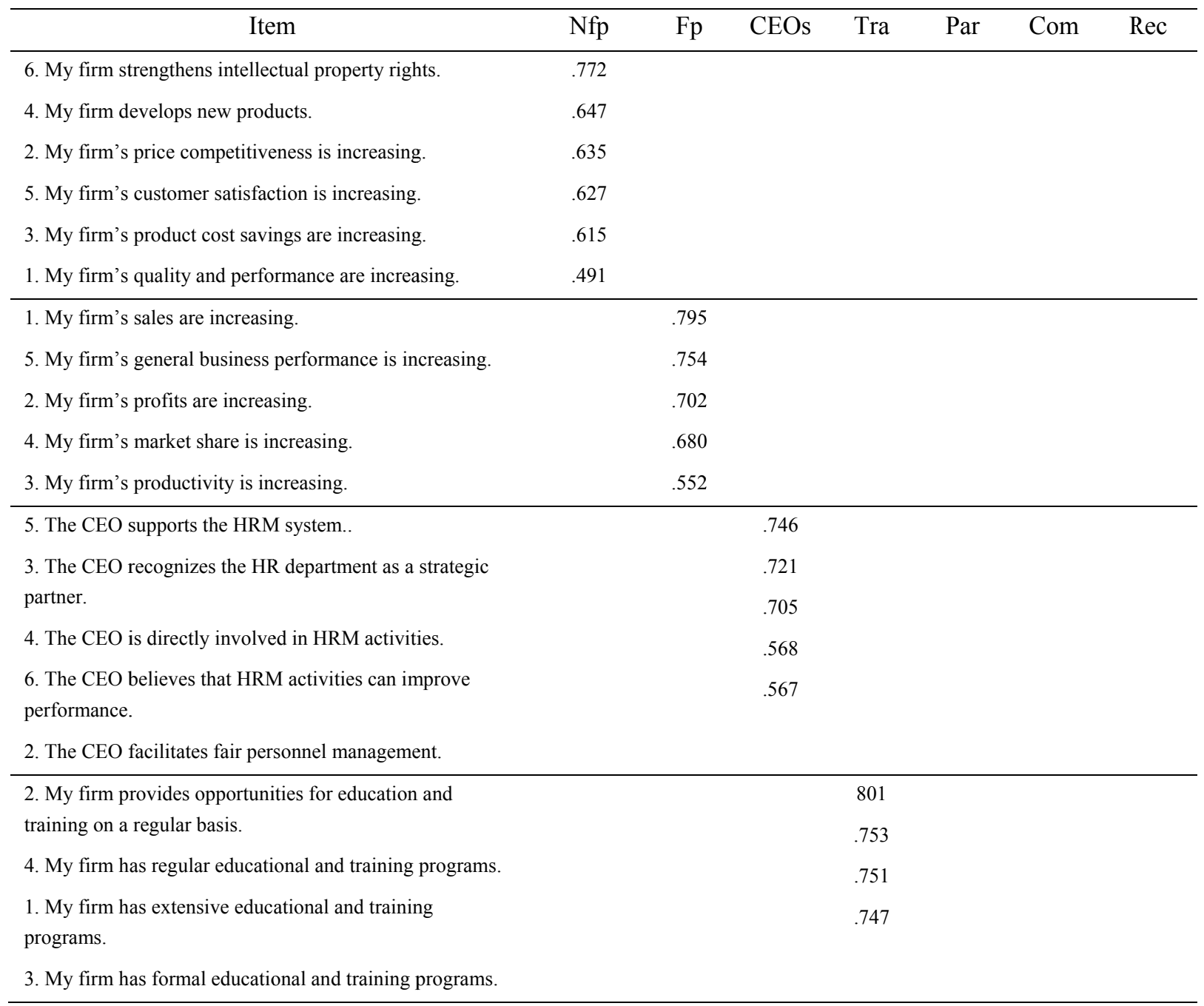


1. My firm involves employees in the decision-making

.816

process.

participate in the decision-making process.

3. My firm provides employees with opportunities to participate in improving the workplace.

4. My firm's top managers and employees communicate smoothly. \begin{tabular}{ll}
\hline 1. Performance items reflect work characteristics. & .796 \\
2. Performance items reflect job requirements for individual & .777 \\
employees. & .775 \\
3. Performance items are objective without performance & \\
estimators' prejudice. &
\end{tabular}

2. My firm formulated exactly the contents of new employees' required skills and abilities.

1. My firm tries to implement various programs to attract more capable employees.

3. My firm pays close attention to the basic quality of employees.

\begin{tabular}{|c|c|c|c|c|c|c|c|}
\hline Eigenvalue & 9.596 & 2.260 & 1.764 & 1.599 & 1.321 & 1.304 & 1.232 \\
\hline$\%$ of the variance explained & 31.987 & 7.534 & 5.880 & 5.329 & 4.404 & 4.347 & 4.108 \\
\hline Total variance & - & 39.521 & 45.401 & 50.729 & 55.133 & 59.480 & 63.588 \\
\hline Number of measured items & 6 & 5 & 5 & 4 & 4 & 3 & 3 \\
\hline Cronbach's alpha & 0.615 & 0.849 & 0.795 & 0.808 & 9.838 & 0.846 & 0.815 \\
\hline
\end{tabular}

Note. $\mathrm{CEOs}=\mathrm{CEO}$ support, Com=Compensation, $\mathrm{Fp}=$ Financial performance, Nfp=Nonfinancial performance, Par=Participation, Rec $=$ Recruitment, Tra $=$ Training.

In the correlation analysis, all correlation coefficients should reflect a normal distribution ranging from - 1.00 to +1.00 (Kline, 2005). Table 3 shows the correlation coefficients of the variables. Most were significant at the 0.01 level.

Table 2. Correlation analysis

\begin{tabular}{|c|c|c|c|c|c|c|c|c|c|c|c|}
\hline Variable & Means & SD & Age & Size & Rec & Tra & Par & Com & CEOs & $\mathrm{Fp}$ & $\mathrm{Nfp}$ \\
\hline Age & 2.273 & 1.002 & 1 & & & & & & & & \\
\hline Size & 5.811 & 2.386 & $.567 * *$ & 1 & & & & & & & \\
\hline Rec & 3.940 & .599 & .044 & .028 & 1 & & & & & & \\
\hline Tra & 3.783 & .744 & .088 & .103 & $.401 * *$ & 1 & & & & & \\
\hline Par & 3.648 & .661 & -.032 & -.034 & $.339 * *$ & $.414 * *$ & 1 & & & & \\
\hline Com & 3.629 & .745 & .101 & .097 & $.305 * *$ & $.344 * *$ & $.354 * *$ & 1 & & & \\
\hline Ceos & 3.697 & .587 & -.009 & -.019 & $.369^{* *}$ & $.434 * *$ & $.527 * *$ & $.489 * *$ & 1 & & \\
\hline $\mathrm{Fp}$ & 3.588 & .635 & .090 & -.083 & $.279 * *$ & $.351 * *$ & $.341 * *$ & $.375^{* *}$ & $.543 * *$ & 1 & \\
\hline Nfp & 3.596 & .591 & $.171^{*}$ & $.178 * *$ & $.344 * *$ & $.423 * *$ & $.403 * *$ & $.382 * *$ & $.551 * *$ & $.613 * *$ & 1 \\
\hline
\end{tabular}

Note. ${ }^{* *}$ and $*$ denote significance at the 0.01 and 0.05 levels, respectively (two-tailed).

As shown in Table 4, all the tolerance values were less than 1, and the VIF values were well below the common threshold of 10.00, indicating that multicollinearity was not a serious issue (Hair et al., 2010). 
Table 3. Multicollinearity

\begin{tabular}{lcc}
\hline Dependent Variable & \multicolumn{2}{c}{ Multicollinearity } \\
\cline { 2 - 3 } & Limit of Tolerance & VIF \\
\hline Recruitment & .771 & 1.297 \\
Training & .697 & 1.435 \\
Participation & .665 & 1.503 \\
Compensation & .715 & 1.399 \\
CEO Support & .507 & 1.972 \\
Financial Performance & .676 & 1.479 \\
\hline
\end{tabular}

Note. The dependent variable was nonfinancial performance.

\subsection{Regression Analysis}

The effects of control variables (firm size and age) on organizational performance were analyzed, although none of their paths were addressed by the hypotheses. According to the results, neither firm size nor firm age had significant positive effects on HRM practices and organizational performance. Therefore, the proposed relationships were verified regardless of firm size and age.

The results show that all F-values were significant and that all regression analyses were suitable. More specifically, the standard coefficients were $\beta=0.165(\mathrm{p}<0.05)$ for training and financial performance, $\beta=0.164$ $(\mathrm{p}<0.05)$ for participation and financial performance, and $\beta=0.227(\mathrm{p}<0.05)$ for compensation and financial performance. This indicates positive relationships between training and financial performance, between participation and financial performance, and between compensation and financial performance. The standard coefficients were $\beta=0.128(p<0.05)$ for recruitment and nonfinancial performance, $\beta=0.202(p<0.05)$ for training and nonfinancial performance, $\beta=0.219(\mathrm{p}<0.05)$ for participation and nonfinancial performance, and $\beta=0.179$ $(p<0.05)$ for compensation and nonfinancial performance. Therefore, there were positive relationships between recruitment and nonfinancial performance, between training and nonfinancial performance, between participation and nonfinancial performance, and between compensation and nonfinancial performance.

Table 4. Regression analysis of linear relationships

\begin{tabular}{|c|c|c|c|c|}
\hline \multirow{3}{*}{ Dependent Variable } & \multicolumn{4}{|c|}{ Organizational Performance } \\
\hline & \multicolumn{2}{|c|}{ Financial Performance } & \multicolumn{2}{|c|}{ Nonfinancial Performance } \\
\hline & $\beta^{1}(\mathrm{t}$-value $)$ & Sig. & $\beta$ (t-value) & Sig. \\
\hline \multicolumn{5}{|l|}{ Control Variable } \\
\hline Firm Age $^{2}$ & $.039(.529)$ & .597 & $.080(1.151)$ & .251 \\
\hline Firm Size ${ }^{3}$ & $.025(.088)$ & .736 & $.098(1.401)$ & .163 \\
\hline \multicolumn{5}{|l|}{ Independent Variable } \\
\hline Recruitment & $.088(1.270)$ & .205 & $.128(1.982)$ & .049 \\
\hline Training & $.165(2.288)$ & .023 & $.202(2.982)$ & .003 \\
\hline Participation & $.164(2.315)$ & .022 & $.219(3.305)$ & .001 \\
\hline Compensation & $.227(3.325)$ & .001 & $.179(2.795)$ & .006 \\
\hline $\mathrm{R}^{2}$ & .229 & & .318 & \\
\hline Adjusted $\mathrm{R}^{2}$ & .206 & & .298 & \\
\hline F-value & 10.221 & .000 & 16.098 & .000 \\
\hline
\end{tabular}

Note. 1: $\beta=$ standard coefficient ( $\mathrm{n}=215) ; 2,3$ : natural $\log$ (two-tailed). 
For the moderating effects, the three-level method suggested by Baron and Kenny (1986) for investigating moderating variables was employed. The first level focuses on control and independent variables; the second one, on moderating variables; and the third one, on interaction effects of independent and moderating variables. In this study, mean centering ((independent variables-mean of independent variables)*(moderating variables-mean of moderating variables) was applied (Aiken \& West, 1991).

Table 5. Moderating effects on financial performance

\begin{tabular}{|c|c|c|c|c|c|c|}
\hline \multirow[t]{2}{*}{ Dependent Variable } & \multicolumn{6}{|c|}{ Financial Performance $(\beta) 1$} \\
\hline & Level 1 & Level 2 & \multicolumn{3}{|c|}{ Level 3} & \\
\hline Firm Age $^{2}$ & .039 & .049 & .044 & .012 & .024 & .031 \\
\hline Firm Size ${ }^{3}$ & .025 & .043 & .035 & .025 & .037 & .051 \\
\hline \multicolumn{7}{|l|}{ Independent Variable } \\
\hline Recruitment(A) & .088 & .042 & .019 & .001 & .035 & .041 \\
\hline Training(B) & $.165^{*}$ & .097 & .079 & .080 & .105 & .081 \\
\hline Participation(C) & $.164^{*}$ & .034 & .035 & .055 & .022 & .037 \\
\hline Compensation(D) & $.227 * *$ & .106 & .102 & .085 & .097 & .095 \\
\hline \multicolumn{7}{|l|}{ Moderate Variable } \\
\hline CEO Support (E) & & $.413^{* *}$ & $.412 * *$ & $.376^{* *}$ & $.388 * *$ & $.374^{* *}$ \\
\hline \multicolumn{7}{|l|}{ Interaction Term } \\
\hline $\mathrm{A} \times \mathrm{E}$ & & & $.103^{\dagger}$ & & & \\
\hline $\mathrm{B} \times \mathrm{E}$ & & & & $.233 * *$ & & \\
\hline $\mathrm{C} \times \mathrm{E}$ & & & & & $.156^{* *}$ & \\
\hline $\mathrm{D} \times \mathrm{E}$ & & & & & & $0.153^{*}$ \\
\hline $\mathrm{R}^{2}$ & .229 & .327 & .336 & .372 & .349 & .347 \\
\hline$\triangle \mathrm{R}^{2}$ & - & $.098^{* *}$ & $.009^{\dagger}$ & $.045^{* *}$ & $.022 * *$ & $.020^{*}$ \\
\hline $\mathrm{F}$ & 10.221 & 14.296 & 12.977 & 15.205 & 13.737 & 13.636 \\
\hline
\end{tabular}

Note. 1: $\beta=$ standard coefficient $(\mathrm{n}=215) ; 2,3$ : natural $\log ;{ }^{\dagger} \mathrm{p}<.10,{ }^{*} \mathrm{p}<.05,{ }^{* *} \mathrm{p}<.01$ (two-tailed).

According to the results, as testing the moderating effect of the CEO support on the relationships between HRM practices and financial performance, except recruitment and financial performance, the financial performance's explanatory increment $\left(\Delta \mathrm{R}^{2}=0.009\right)$ was not significantly increased while others were significantly increased as a result of the addition of the interaction variable. The coefficients were $\beta=0.233(p<0.01)$ for the interaction effect of training and financial performance, $\beta=0.156(\mathrm{p}<0.01)$ for that of participation and financial performance, and $\beta=0.153(p<0.05)$ for compensation and financial performance. The results indicate that CEO support moderated the relationships between training and financial performance, between participation and financial performance, and between compensation and financial performance. Meanwhile, as testing the moderating effect of the CEO support on the relationships between HRM practices and nonfinancial performance, there were no significant nonfinancial performance's explanatory increases as a result of the addition of the interaction variable except training. The coefficient for training and nonfinancial performance was $\beta=0.121(p<0.05)$, whereas the other coefficients were not significant. In this regard, it can be concluded that CEO support moderated the relationship only between training and nonfinancial performance.

These results provide support for $\mathrm{H} 1$ except for H1-1a. In addition, they provide support only for H2-2a, H2-3a, H2-4a, and H2-2b. 
Table 6. Moderating effects on nonfinancial performance

\begin{tabular}{|c|c|c|c|c|c|c|}
\hline \multirow[t]{2}{*}{ Dependent Variable } & \multicolumn{6}{|c|}{ Nonfinancial Performance $(\beta) 1$} \\
\hline & Level 1 & Level 2 & \multicolumn{3}{|c|}{ Level 3} & \\
\hline Firm $\mathrm{Age}^{2}$ & .080 & .089 & .088 & .070 & .080 & .089 \\
\hline Firm Size ${ }^{3}$ & .098 & $.114^{\dagger}$ & $.112^{\dagger}$ & .105 & $.112^{\dagger}$ & $.115^{\dagger}$ \\
\hline \multicolumn{7}{|l|}{ Independent Variable } \\
\hline Recruitment(A) & $.128^{*}$ & .087 & .079 & .065 & .084 & .087 \\
\hline Training(B) & $.202 * *$ & $.140^{*}$ & $.134 *$ & $.131^{*}$ & $.143^{*}$ & $.139 *$ \\
\hline Participation $(\mathrm{C})$ & $.219^{* *}$ & .101 & .101 & $.112 \dagger$ & .096 & .101 \\
\hline Compensation(D) & $.179^{* *}$ & .069 & .067 & .058 & .065 & .068 \\
\hline \multicolumn{7}{|l|}{ Moderate Variable } \\
\hline CEO Support (E) & & $.377 * *$ & $.377 * *$ & $.358 * *$ & $.368 * *$ & $.376^{* *}$ \\
\hline \multicolumn{7}{|l|}{ Interaction Term } \\
\hline $\mathrm{A} \times \mathrm{E}$ & & & .034 & & & \\
\hline $\mathrm{B} \times \mathrm{E}$ & & & & $.121^{*}$ & & \\
\hline $\mathrm{C} \times \mathrm{E}$ & & & & & .058 & \\
\hline $\mathrm{D} \times \mathrm{E}$ & & & & & & .006 \\
\hline $\mathrm{R}^{2}$ & .318 & .400 & .401 & .413 & .403 & .400 \\
\hline$\triangle \mathrm{R}^{2}$ & - & $.082 * *$ & .001 & $.012 *$ & .003 & .000 \\
\hline $\mathrm{F}$ & 16.098 & 19.646 & 17.178 & 18.002 & 17.329 & 17.019 \\
\hline
\end{tabular}

Note. 1: $\beta=$ standard coefficient $(\mathrm{n}=215) ; 2,3$ : natural log; $\uparrow \mathrm{p}<.10,{ }^{*} \mathrm{p}<.05,{ }^{* *} \mathrm{p}<.01$ (two-tailed).

\section{Discussions and Conclusions}

This study investigates the relationships between HRM practices and organizational performance by focusing on the moderating effect of CEO support. The results reveal that HRM practices, training, participation, and compensation had positive effects on financial performance and that recruitment, training, participation, and compensation had positive effects on nonfinancial performance. CEO support moderated the relationship between HRM practices and financial performance and that between training and nonfinancial performance.

The results are consistent with the findings of Kotey and Meredith (1997) and Heneman and Berkley (1999), who found positive relationships between specific HRM practices and organizational performance except for recruitment. Although most studies demonstrated positive relationships between strategic recruitment and firm outcomes for Chinese firms, particularly for small and medium-sized ones (Zheng et al., 2006), in our data, the respondents were those CEOs or general leaders who maybe not participate in the recruitment process directive, then some uncontrollable bias were inevitable. Therefore, the results do not verify a positive relationship between recruitment and financial performance. In addition, the results are consistent with the findings of previous studies demonstrating the significant positive effect of training activities on organizational performance and suggest that these activities represent "best practices" based on the findings of Pfeffer (1994) and Delaney and Huselid (1996). On the other hand, the results indicate that CEO support moderated the relationship between training and nonfinancial performance but not the relationships between other HRM practices and nonfinancial performance. This suggests that training activities can be considered an important factor in the initial stages of gaining a competitive advantage, as indicated in Barney (1991). The validity of the results may be limited because the regression models rely on the assumption that HRM activities influence financial as well as nonfinancial performance, which is consistent with Harel and Tzafrir (1999).

The results suggest that recruitment, training, participation, and compensation can enhance HRM effectiveness and sales per employee when the CEO acknowledges the firm's HR department as an important part of management and directly participates in or support the department. Therefore, CEO support can be viewed as an 
essential factor in HRM practices as well as in other management activities. In terms of HR-based CEO support, it is important to make the CEO perceive the importance of strategic HR policies and activities. If managers have negative attitudes toward the HR department or HRM activities, then the organization cannot gain a competitive advantage or enhance its performance regardless of the quality of its personnel management or HRM practices.

The results reveal that the implementation of HRM practices remains in the initial stages in China. This may be because private enterprises, particularly small and medium-sized service firms, still tend to focus more on profits than on paying out a lot of money in pursuit of strategic HRM practices. That is, Chinese CEOs have yet to consider HRM practices as critical. However, CEOs of state-owned enterprises may fare better because they can employees with training opportunities or sufficient compensation on a regular basis without being heavily limited by the need to make profits.

In this study, $60.4 \%$ of the respondents were SMEs, and 39.6\%, large firms. In this regard, the study contributes to the literature on SMEs' HRM practices of Chinese firms. In addition, manufacturing firms accounted for $26 \%$ of the sample, whereas other types of firms, $74 \%$. Therefore, this study also contributes by considering HRM practices in various business fields of Chinese firms. Finally, the study demonstrates the moderating effects of HR-based CEO support and verifies that it is more important than other factors.

\section{Limitations and Future Research}

This study investigates the relationship between HRM practices and organizational performance and the moderating effect of CEO support on this relationship. Although its methodology and data collection method are rigorous in nature, it has some limitations.

One limitation derives from its characteristic of the data collection. The respondents were those working for a limited number of Chinese firms. Because different cities have different cultures, the results, which are based on a small number of firms, may not fully reflect the characteristics of firms across China. In this regard, future research should consider larger samples.

In addition to sample size, a more diverse range of firms should be considered, which should enhance the reliability, validity, persuasiveness, and universality of collected data. Further, future research should focus on mediating and moderating variables because mediating variables may be closely related to some HRM outcomes, whereas moderating ones, to some HRM practices. Another interesting avenue for future research is the investigation of the effects of ownership and labor unions in the context of Chinese firms. China is a socialist state but has a rapidly growing economy, and therefore HRM practices may play a critical role in Chinese organizations. For example, many organizations tend to recruit members of the Communist Party of China because of their loyalty, but recent recruitment processes have witnessed an increasing number of Chinese firms paying closer attention to employees' ability and knowledge than to their status. In other words, CEOs are increasingly focusing on HRM practices. In addition, CEOs are gradually paying attention to employee compensation. They are not only taking part in determining bonuses but also giving them to employees directly. In addition, they tend to encourage employees to enhance their individual performance. In other words, HR-based CEO support can be useful for helping HR departments design or implement HRM practices to increase employee performance to gain a competitive advantage in China's modern society.

\section{References}

Ahire, S. L. (1996). An empirical investigation of quality management in small firms. Production and Inventory Management Journal, 2, 44-50. Retrieved from http://www.riss.kr/search/detail/DetailView.do? p_mat_type=e21c2016a7c3498b\&control_no=5c35218e5ae7e3a4ffe0bdc3ef48d419

Aiken, L., \& West, S. (1991). Multiple Regression: Testing and Interpreting Interactions. Newbury Park, CA: Sage.

Akgun, A. E., Keskin, H., Byrne, J. C., \& Aren, S. (2007). Emotional and learning capability and their impact on product innovativeness and firm performance. Technovation, 27, 501-513. http://dx.doi.org/10.1016/ j.technovation.2007.03.001

ALDamoe, F. A., Yazam, M., \& Hamid, K. A. (2013). Human Resource Management Practices on Organizational Performance in Libya Firm. Public Administration Research, 2(1), 29-32. http://dx.doi.org/ 10.5539/par.v2n1p29

Baron, R.M., \& Kenny, D.A. (1986). The moderator-mediator variable distinction in social psychological research: conceptual, strategic and statistical considerations. Journal of Personality \& Social Psychology, 51, 1173-1182. http:// dx.doi.org/ 10.1037/0022-3514.51.6.1173 
Barney, J. (1991). Firm resources and sustained competitive advantage. Journal of Management, 17, 99-120. http:// dx.doi.org/ 10.1016/S0742-3322(00)17018-4

Bartel, A. P. (1994). Productivity gains from the implementation of employee training programs. Industrial Relations, 33, 411-425. http://dx.doi.org/ 10.1111/j.1468-232X.1994.tb00349.x

Becker, B., \& Gerhart, B. (1996). The Impact of Human Resource Management on Organizational Performance:Progress and Prospects. Strategic Management Journal, 39, 779-801. http://dx.doi.org/ $10.2307 / 256712$

Becker, B. E., \& Huselid, M. A. (1998). Human resources strategies, complementarities, and firm performance. Paper presented at the 1997 Academy of Management Annual Meeting, Boston, MA. Abstract retrieved from http://mgt.buffalo.edu/departments/ohr/becker/publications/HumanResourcesStrategies.pdf

Blinder, A. S. (1990). Paying for productivity. Washington, DC.

Boselie, P., Dietz, G., \& Boon, C. (2005). Commonalities and contradictions in HRM and performance research. Human Resource Management Journal, 15, 67-94. http:// dx.doi.org/10.1111/j.1748-8583.2005.tb00154.x

Boselie, P., Paauwe, J. \& Jansen, P. (2001). Human resource management and performance: Lessons from the Netherlands. International Journal of Human Resource Management, 12, 1107-1125. http://dx.doi.org/ $10.1080 / 09585190110068331$

Bowen, D. E., \& Ostroff, C. (2004). Understanding HRM-firm performance linkages: The role of the "Strength" of the HRM system. Academy of Management Review, 29(2), 203-221. http://dx.doi.org/10.5465/AMR. 2004.12736076

Burke, J. M., \& Day, R. R. (1986). A cumulative study of the effectiveness of managerial training. Journal of Applied Psychology, 71, 232-245. http://dx.doi.org/ 10.1037/0021-9010.71.2.232

Collins, C. J., \& Smith, K. G. (2006). Knowledge exchange and combination: The role of human resource practices in the performance of high-technology firms. Academy of Management Journal, 49(3), 544-560. http:// dx.doi.org/10.5465/AMJ.2006.21794671

Delaney, T. J., \& Huselid, A. M. (1996). The impact of human resource management practices on perceptions of organizational performance. Academy of Management Journal, 39, 949-969. http://dx.doi.org/10.2307/ 256718

Dreher, A. (2006). Does Globalization Affect Growth? Evidence from a new Index of Globalization. Applied Economics, 38(10), 1091-1110. http:// dx.doi.org/ 10.1080/00036840500392078

Fraenkel, J. R., \& Wallen, N. E. (1996). How to design and evaluate research in education (3th ed.). New York: McGraw-Hill. Retrieved from http://doha.ac.mu/ebooks/Research\%20Methods/DesigningAndEvaluating ResearchInEducation.pdf

Gerhart, B. (2005). Human resources and business performance: Findings, unanswered questions, and an alternative approach. Management Revue, 16, 174-185

Gomez-Mejia, L. R., \& Wellbourne, V. T. (1988). Compensation strategy: An overview and future steps. Human Resource Planning, 11, 173-189. Retrieved from http://wenku.baidu.com/link?url=K6cP1cECGHcDc DYZQMpljzXRsSCuoZz47T_MNKSu719olYfi6BaNkjkO1oZLhrGeGooh4JOuFxOfZP42ADXPmiQnDBE HelAoVdF1YgSDvm

Greenley, G. E., \& Foxall, G. R. (1998). External Moderation of Associations among Stakeholder Orientations and Company Performance. International Journal of Research in Marketing, 15(1), 51-69. http://dx.doi.org/ 10.1016/S0167-8116(97)00018-9

Größler, A., \& Zock, A. (2010). Supporting long-term workforce planning with a dynamic aging chain model; a case study from the service industry. Human Resource Management, 49(5), 829-848. http://dx.doi.org/ $10.1002 / \mathrm{hrm} .20382$

Hailey, V. H., Farndale, E., \& Truss, C. (2005). The HR department's role in organizational performance. Human Resource Management Journal, 15(3), 49-66. http://dx.doi.org/10.1111/j.1748-8583.2005.tb00153.x

Hair, J. F., Black, B., Babin, B. J., \& Anderson, R. E. (2010). Multivariate Data Analysis (7th ed.). A Global Perspective, New Jersey, USA: Person Education Inc.

Harel, G. H., \& Tzafrir, S. S. (1999). The effect of human resource management practices on the perception of organizational and market performance of the firm. Human Resource Management, 38, 185-201. 
http://dx.doi.org/10.1002/(SICI)1099-050X(199923)38:3<185::AID-HRM2>3.0.CO;2-Y

Heneman, H. G. (III), \& Berkley, R. (1999). Applicant attraction practices and outcomes among small businesses. Journal of Small Business Management, 37, 53-74. Retrieved from http://www.riss.kr/search/detail/ DetailView.do?p_mat_type $=$ 21c2016a7c3498b\&control_no=1bdc35b0297a5d84

Jackson, S. E., \& Schuler, R. S. (2000). Managing human resources: A partnership perspective (7th ed.). Cincinnati, OH: South-Western Publishing.

Jacob, C., \& Jolly, J. (2012). Impact of Nationality on Employees' Perception towards Human Resource Management Policies. Asian Social Science, 8(15), 31-45. http://dx.doi.org/ 10.5539/ass.v8n15p31

Jain H. C. (1980). Worker Participation: Success and Problems. New York, NY.

Jung, K. T., Park, K. K., \& Lim, H. C. (2008). The Effects of performance-based HR Practices on Firm Performance. HR Development Studies, 11(2), 79-106. Retrieved from http://www.riss.kr/search/detail/ DetailView.do?p_mat_type=1a0202e37d52c72d\&control_no=40b55aacea86887bffe0bdc3ef48d419

Jyothi, P., \& Venkatesh, D. N. (2006), Human resource management. New Delhi: Oxford University Press.

Katou, A. A. (2008). Measuring the impact of HRM on organizational performance. Journal of Industrial Engineering and Management, 1(2), 119-142. http://dx.doi.org/10.3926/jiem.2008.v1n2.p119-142

Kaufman, T. R. (1992). The effects of IMPROSHARE on productivity. Industrial and Labor Relations Review, 45, 311-322. Retrieved from http://connection.ebscohost.com/c/articles/9202240182/effects-improshare -productivity

Kline, R. B. (2005). Principles and Practices of Structural Equation Modeling (2nd ed.). New York: The Guilford Press.

Kotey, B., \& Meredith, G. G. (1997). Relationship among Owner/Manager Personal Values, Business Strategies and Enterprise Performance. Journal of Small Business Management, 35(2), 37-61. Retrieved from http://directory.umm.ac.id/sistem-pakar/9706013173.pdf

Laabs, J. J. (1991). Team Training Goes Outdoors. Personnel Journal, 70, 56-63.

Levesque, L. L. (2005). Opportunistic hiring and employee fit. Human Resource Management, 44(3), 301-317. http://dx.doi.org/ 10.1002/hrm.20072

Li, E. Y., Chen, H. G., \& Cheung, W. (2000). Total quality management in software development process. The Journal of Quality Assurance Institute, 4, 35-41. http:// dx.doi.org/ 10.1002/0471028959.sof360

Losey, M. R. (1993). Is sexual orientation an issue in the workplace. HR News, 12, 16-17.

Martell, K., \& Carroll, S. J. (1995). How Strategic is HRM. Human Resource Management, 34(2), 253-267. http:// dx.doi.org/ 10.1002/hrm.3930340203

Martinez, M. (1993). Recognizing sexual orientation is fair and not costly. HRM magazine, 38, 66-72.

Peteraf, M. A. (1993). The Cornerstones of Competitive Advantage: A Resource-Based View. Strategic Management Journal, 14(3), 179-191. http:// dx.doi.org/10.1002/smj.4250140303

Pfeffer, J. (1994). Competitive advantage through people: Unleashing the power of the work force. Harvard Business School Press, Boston, MA.

Pfeffer, J. (2000). Seven practices of successful organizations. In W. L. French, C. H. Bell, \& J. Pfeffer (Eds.), Seven practices of successful organizations (pp. 96-124). California Management Review.

Rogers, E. W., \& Wright, P. M. (1998). Measuring organizational performance in strategic human resource management: problems and prospects. Human Resource Management Review, 8(3), 311-331. http://dx.doi.org/10.1016/S1053-4822(98)90007-9

Rynes, S., \& Rosen, B. (1995). A field survey of factors affecting the adoption and perceived success of diversity training. Personnel Psychology, 48, 247-270. http://dx.doi.org/10.1111/j.1744-6570.1995.tb01756.x

Schuler, R. S., \& Jackson, S. E. (1987). Linking competitive strategies with human resource management practices. Academy of Management Executive, 1, 207-219. http:// dx.doi.org/ 10.5465/AME.1987.4275740

Seal, K. (1991). Sexual orientation becomes workplace issue for the 1900s. Hotel \& Motel Management, 206, 2-29.

Smith, B. (1991). Diversity with a difference. HR Focus, 68. 
Sureshchandar, G. S., Rajendran, C., \& Anantharaman, R. N. (2001). A holistic model for total quality service. International Journal of Service Industry Management, 12, 378-412. http://dx.doi.org/10.1108/ 09564230110405299

Sureshchandar G. S., Rajendran, C., \& Anantharaman, R. N. (2002). The relationship between management's perception of total quality service and customer perceptions of service quality. Total Quality Management, 13, 69-88. http://dx.doi.org/10.1080/09544120120098573

Terpstra, D. E., \& Rozell, E. J. (1993). The relationship of staffing practices to organizational level measures of performance. Personnel Psychology, 46-48. http://dx.doi.org/10.1111/j.1744-6570.1993.tb00866.x

Ulrich, D. (1998). A new mandate of human resources. Harvard Business Review, 41(1), 4-134.

U. S. Department of Labor. (1993). High Performance Work Practices and Firm Performance. Government Printing Office, Washington, DC.

Vangelis, S., \& Marcello. B. M. Maestro. (2010). Poly-chronicity in top management teams: The impact on strategic decision processes and performance of new technology ventures. Strategic Management Journal, 31(6), 652-679. http:// dx.doi.org/ 10.1002/smj.831

Verma, A. (1995). Employee involvement in the workplace. In M. Gunderson, \& A. Ponak (Eds.), Union-management relations (pp. 281-308). Canada.

Wagner, A. J. (1994). Participation's effects on performance and satisfaction: A reconsideration of research evidence. Academy of Management Review, 19, 312-330. http://dx.doi.org/10.5465/AMR.1994.9410210753

Wall, T. D., \& Wood, S. J. (2005). The romance of human resource management and business performance, and the case for big science. Human Relations, 58(4), 429-462. http://dx.doi.org/10.1177/0018726705055032

Williamson, A. D. (1993). Is this the right time to come out. Harvard Business Review, 18-27.

Yazam, M., \& Ahmid, K. B. (2011). The Mediating Effect of HRM Outcomes (employee retention) on the Relationship between HRM Practices and Organizational Performance. International Journal of Human Resource Studies, 2(1), 75-88. http://dx.doi.org/10.5296/ijhrs.v2i1.1252

Zheng, C., Morrison, M., \& O'neill, G. (2006). An Empirical Study of High Performance HRM Practices in Chinese SMEs. International Journal of Human Resource Management, 17(10), 1772-1803. http://dx.doi.org/ 10.1080/09585190600965282

\section{Copyrights}

Copyright for this article is retained by the author(s), with first publication rights granted to the journal.

This is an open-access article distributed under the terms and conditions of the Creative Commons Attribution license (http://creativecommons.org/licenses/by/3.0/). 